\title{
Pengaruh Struktur Modal, Profitabilitas, dan Ukuran Perusahaan Terhadap Nilai Perusahaan Pada Perusahaan Indeks BUMN20 yang Terdaftar di Bursa Efek Indonesia Tahun 2018-2019
}

\author{
1Siti Fatimah*, 2Azib \\ Bandung, Indonesia. \\ *1sitifatimah2727@gmail.com, 2azib_asroi@yahoo.co.id
}

Prodi Manajemen, Fakultas Ekonomi dan Bisnis, Universitas Islam

\begin{abstract}
This study aims to determine the effect of capital structure, profitability, and firm size on firm value in BUMN20 index companies listed on the Indonesia Stock Exchange in 2018-2020. Based on the criteria using the purposive sampling method, a sample of 16 SOEs 20 index companies listed on the Indonesia Stock Exchange was obtained. Panel data regression analysis was used as an analytical method assisted by the Eviews 10 program. The results of this study indicate that there is a simultaneous influence between capital structure, profitability, and firm size on firm value (Tobin's Q). Partially, the capital structure calculated through DER (Debt Equity Ratio) and firm size have no significant effect on firm value. Profitability calculated through ROA (Return On Assets) has a positive and significant effect on firm value. While profitability calculated through ROE (Return On Equity) has a negative and significant effect on firm value.
\end{abstract}

Keywords: Capital Structure, Profitability, ROA (Return On Assets), ROE (Return On Equity)

\begin{abstract}
Abstrak. Penelitian ini bertujuan untuk mengetahui pengaruh struktur modal, profitabilitas, dan ukuran perusahaan terhadap nilai perusahaan pada perusahaan indeks BUMN20 yang terdaftar di Bursa Efek Indonesia tahun 2018-2020. Berdasarkan kriteria dengan menggunakan metode purposive sampling, diperoleh sample sebanyak 16 perusahaan indeks BUMN20 yang terdaftar di Bursa Efek Indonesia. Analisis regresi regresi data panel digunakan sebagai metode analisis dibantu oleh program Eviews 10. Hasil penelitian ini menunjukkan bahwa terdapat pengaruh antara struktur modal, profitabilitas, dan ukuran perusahaan terhadap nilai perusahaan (Tobin's Q) secara stimultan. Secara parsial, struktur modal yang dihitung melalui DER (Debt Equity Ratio) dan ukuran perusahaan tidak berpengaruh signifikan terhadap nilai perusahaan. Profitabilitas yang dihitung melalui ROA (Return On Asset) berpengaruh positif dan signifikan terhadap nilai perusahaan. Sedangkan profitabilitas yang dihitung melalui ROE (Return On Equity) berpengaruh negatif dan signifikan terhadap nilai perusahaan
\end{abstract}

Kata Kunci: Struktur Modal, Profitabilitas, ROA (Return On Asset), ROE (Return On Equity). 


\section{A. Pendahuluan}

Pertumbuhan ekonomi dunia mengalami perubahan besar di era globalilasi yang semakin maju ini. Banyak pesaing didalam dunia bisnis yang sangat menuntut para pemimpin perusahaan untuk lebih kompetitif supaya mampu mengelola dengan efektif dan efisien sumber daya perusahaannya. Resiko ketidakpastian di dalam dunia pasar keuangan selalu menambah tekanan bagi perusahaan dalam menerapkan rencana dan strategi agar terhindar dari kerugian yang tidak diharapkan. Hal ini tentu perlu diperhatikan oleh perusahaan yang ada di Indonesia agar bisa mempersiapkan diri untuk menghadapi persaingan bisnis nasional maupun internasional agar menghasilkan kinerja perusahaan yang lebih baik. Banyak perusahaan go public yang berusaha unyuk memaksimalkan nilai perusahaannya demi kesejahteraan para pemegang saham dan agar dapat bersaing di dunia bisnis.

Dikatakan bahwa bisnis lebih dipercaya dibandingkan pemerintah. Dalam survei Endelmen yang melakukan studi pada 21 pasar mencatat bahwa kepercayaan masyarakat Indonesia terhadap bisnis sebesar $78 \%$ sedangkan untuk perusahaan pemerintah sebesar $73 \%$ (Edelman Trust Barometer, 2018). Badan Usaha Milik Negara (BUMN) adalah bentuk usaha yang dikelola dan dimiliki oleh negara. BUMN merupakan salahsatu sumber penerimaaan negara baik berupa profit, pajak, dan hasil industri sehingga mampu memberi sumbangsih untuk mempercepat pertumbuhan ekonomi secara nasional.

Pada tahun 2018, Bursa Efek Indonesia meluncurkan tiga indeks baru, salah satunya adalah IDX BUMN 20 (Indonesia Stock Exchange Badan Usaha Milik Negara 20). Menurut Direktur Utama BEI, Tito Sulistio "peluncurkan indeks baru ini berguna untuk mempermudah investor dalam memilih saham yang akan diinvestasikan.". Dapat dilihat bahwa pembelian saham saat awal pandemi sempat mengalami penurunan, hal tersebut juga terjadi pada indeks saham lainnya. Namun, pada bulan berikutnya tingkat pembelian IDX BUMN 20 terus mengalami peningkatan. Hal tersebut menunjukkan bahwa IDX BUMN 20 sebagai pasar yang banyak diminati oleh banyak investor karena nilai kapitalisasi pasar ini banyak mempengaruhi investor untuk memilih saham.

Tujuan utama dari perusahaan sudah go public seperti dalam indeks BUMN20 yaitu untuk menghasilkan laba guna meningkatkan kemakmuran pemilik atau para pemegang saham melalui peningkatan nilai perusahaan agar dapat menggambarkan keadaan perusahaan. perusahaan akan dipandang semakin bernilai oleh para calon investor ketika semakin baiknya nilai perusahaan. Namun yang perlu diketahui, tidak semua investor akan menginvestasikan uangnya pada perusahaan. Beberapa hal yang sering dilihat investor sebelum memutuskan berinvestasi pada suatu perusahaan. salah satu pertimbangan investor sebelum memutuskan untuk memberikan dana kepada perusahaan adalah nilai perusahaan.

Struktur modal (capital structure) ini berkaitan dengan pembelanjaan jangka panjang sebuah perusahaan yang dapat diukur dengan membandingkan utang jangka panjang dengan modal perusahaan itu sendiri (Sundana, 2015:143). Struktur modal yang baik akan menekan pengeluaran biaya modal suatu perusahaan. Sedangkan struktur modal yang buruk akan mempengaruh tingginya biaya modal yang dikeluarkan perusahaan.

Beberapa penelitian terdahulu yang berkaitan dengan struktur modal menunjukkan hasil yang beragam seperti pada penelitian Tunggul Priyatama dan Eka Pratini (2021) yang menghasilkan bahwa struktur modal berpengaruh positif dan signifikan terhadap nilai perusahaan. Pada penelitian Mispiyanti (2020) juga menemukan bahwa struktur modal tidak mempengaruhi nilai perusahaan.

Menurut penelitian Indasari dan Yadnyana, (2018) nilai perusahaan juga dapat dipengaruhi oleh besar kecilnya profitabilitas yang dihasilkan oleh perusahaan. Semakin tinggi tingkat profitabilitas maka semakin tinggi nilai perusahaan maka semakin besar kemakmuran yang akan dibagikan kepada pemegang saham, oleh karena itu tingkat profitabilitas berpengaruh positif pada nilai perusahaan. Pada penelitian Hamidy et al., (2015) menemukan bahwa investor tertarik untuk menanamkan sahamnya pada perusahaan yang memberikan keuntungan besar karena semakin tinggi profitabilitas maka perusahaan dapat menghasilkan keuntungan yang tinggi bagi pemegang saham. Penelitian ini didukung oleh penelitian Monica dan Jonnardi (2021) serta Zahra, Ikin, Maya (2019) yang menyatakan bahwa profitabilitas berpengaruh 
positif terhadap nilai perusahan.

Selain itu, ukuran perusahaan juga dinilai mampu mempengaruhi nilai perusahaan. Semakin besar ukuran perusahaan maka semakin mudah pula perusahaan memperoleh sumber pendanaan baik yang bersifat internal maupun eksternal. Sehingga perusahaan akan lebih banyak mendapatkan peluang memperoleh laba yang lebih tinggi. Dengan semakin tingginya perolehan laba akan meningkatkan harga saham perusahaan yang pada ujungnya akan meningkatkan nilai perusahaan.

Semakin besar ukuran perusahaan maka ada kecenderungan lebih banyak investor yang menaruh perhatian pada perusahaan tersebut, sehingga akan meningkatkan nilai perusahaan dimata investor, hal ini disebabkan karena perusahaan yang besar cenderung memiliki kondisi yang lebih stabil. Semakin besar skala atau ukuran suatu perusahaan, maka akan semakin mudah bagi perusahaan dalam mendapatkan sumber pendanaan dari internal maupun eksternal, karena probabilitas yang dimiliki perusahaan untuk bertahan dalam industri relatif lebih besar.

Berdasarkan latar belakang diatas, maka penulis mengidentifikasi masalah penelitian sebagai berikut:

1. Apakah struktur modal (DER) profitabilitas melalui return on asset (ROA) dan return on equity (ROE), serta ukuran perusahaan (Size) berpengaruh secara simultan dan parsial terhadap nilai perusahaan (Tobin's Q) pada perusahaan indeks BUMN20 yang terdaftar di Bursa Efek Indonesia tahun 2018-2020?

\section{B. Metodologi Penelitian}

Metode penelitian yang digunakan dalam penelitian ini adalah metode penelitian verifikatif dengan pendekatan kuantitatif. Metode penelitian ini digunakan untuk menggambarkan masingmasing pengaruh struktur modal, profitabilitas, dan ukuran perusahaan terhadap nilai perusahaan. Dalam penelitian ini yang menjadi sasaran peneliti adalah seluruh perusahaan yang masuk dalam indeks BUMN20 di Bursa Efek Indonesia periode 2018-2020. Sampel yang digunakan dalam penelitian ini sebanyak 16 perusahaan indeks BUMN20 yang di Bursa Efek Indonesia dengan menggunakan metode purposive sampling. Jumlah tahun penelitian adalah 3 tahun, maka total data penelitian adalah 48 .

Pengumpulan data yang dimulai dengan tahap penelitian pendahuluan, yaitu dengan melakukan studi kepustakaan dengan membaca dan mempelajari buku-buku bacaan serta materi yang ada kaitannya dengan pokok bahsan yang terdapat dalam penelitian. Pengkajian data juga dilakukan pada tahap ini, diantaranya mengenai jenis-jenis data yang dibutuhkan, adanya ketersediaan data, bagaimana cara mengumpulkan dan mengolah data yang baik. Dalam penelitian ini, pengolahan data dilakukan dengan menggunakan aplikasi eviews 10 .

\section{Nilai Perusahaan}

Menurut Suad (2008:7), nilai perusahaan merupakan harga yang bersedia dibayar oleh calon pembeli apabila perusahaan tersebut dijual.

Dalam penelitian ini, rasio nilai perusahaan yang digunakan adalah Rasio Tobin's Q. Indikator Nilai Perusahaan Pada penelitian ini pendekatan harga saham digunakan untuk menentukan nilai perusahaan.

$$
\mathbf{Q}=\frac{(E M V+D)}{(E B V+D)}
$$

\section{Struktur Modal}

Struktur modal merupakan kemampuan perusahaan dalam memenuhi kewajiban jangka panjangnya. Suatu perusahaan tentu memerlukan modal yang berasal dari utang maupun ekuitas. Struktur modal yang optimal sangat diperlukan guna mengkombinasikan antara utang dan ekuitas yang bertujuan untuk memaksimumkan harga saham perusahaan. (Brigham dan Houston, 2001:5). Dalam penelitian ini, pengukuran struktur modal menggunakan rasio Debt to equity ratio (DER), secara sistematis dapat dirumuskan sebagai berikut :

\section{Total Hutang}




DER $=\quad$ Total Modal

\section{Profitabilitas}

Profitabilitas adalah kemampuan perusahaan menghasilkan laba atau ukuran efektivitas pengelolaan manajemen perusahaan (Wiagustini, 2010). Rasio profitabilitas adalah rasio untuk menilai kemampuan perusahaan dalam mencari profit atau laba dalam satu periode tertentu. Rasio profitabilitas adalah rasio yang dipakai untuk mengetahui bagaimana kemampuan perusahaan dalam menghasilkan laba (Pratiwi, 2020).

Pengukuran rasio profitabilitas dalam penelitian ini yaitu, ROA dan ROE.

Return on Assets (ROA) merupakan rasio keuangan perusahaan yang berhubungan dengan profitabilitas mengukur kemampuan perusahaan menghasilkan keuntungan atau laba pada tingkat pendapatan, aset dan modal saham tertentu. Dengan mengetahui ROA, kita dapat menilai apakah perusahaan telah efisien dalam menggunakan aktivanya dalam kegiatan operasi untuk menghasilkan keuntungan (Hanafi dan Halim, 2003:27).

ROA $=\frac{\text { Laba Sebelum Pajak }}{\text { Total Asset }} \quad$ X 100\%

Return on Equity (ROE) adalah rasio ini di gunakan untuk mengukur tingkat pengembalian dari bisnis atas seluruh modal yang ada. Menurut Syamsudin (2016) ROE adalah pengukuran dari penghasilan yang tersedia bagi para pemilik perusahaan atas modal yang diinvestasikan di dalam perusahaan.

\begin{tabular}{|c|c|c|}
\hline \multirow{2}{*}{$\mathrm{ROE}=$} & Laba Bersih & \multirow{2}{*}{ X $100 \%$} \\
\hline & Total Ekuitas & \\
\hline
\end{tabular}

\section{Ukuran Perusahaan}

Ukuran Perusahaan (Firm Size) adalah skala untuk menentukan besar kecilnya suatu perusahaan yang dapat diproksikan dengan beberapa cara, antara lain total aktiva (Total Assets) dan total penjualan (Total Sales) (Saemargani, 2015). Dalam penelitian ini ukuran perusahaan diukur menggunakan logaritma natural (Ln) dari total aset yang dimiliki perusahaan yang dapat dirumuskan sebagai berikut.

Ukuran Perusahaan $=$ Ln $($ Total asset $)$

\section{Hasil Penelitian dan Pembahasan}

Uji Regresi Data Panel

Tabel 1. Uji Chow

\begin{tabular}{cccc}
\hline \hline Effects Test & Statistic & d.f. & Prob. \\
\hline \hline Cross-section F & 8.297192 & $(15,28)$ & 0.0000 \\
Cross-section Chi-square & 81.344823 & 15 & 0.0000 \\
\hline \hline
\end{tabular}

Dari hasil pengujian dengan uji chow diatas diperoleh nilai probability pada cross section F sebesar 0,0000 dimana nilai tersebut lebih kecil dari nilai signifikansi yaitu 0,05 (5\%) 
maka H0 ditolak dan Ha diterima, Ha pada uji chow adalah model fixed effect, maka model yang tepat untuk penelitian ini adalah model fixed effect.

\section{Uji Hausman}

Tabel 2. Uji Hausman

\begin{tabular}{lcrr}
\hline \hline Test Summary & Chi-Sq. Statistic & Chi-Sq. d.f. & Prob. \\
\hline \hline Cross-section random & 2.512874 & 4 & 0.6423 \\
\hline \hline
\end{tabular}

Dari hasil pengujian dengan uji Hausman diatas diperoleh nilai probability pada cross section random sebesar 1,0000 dimana nilai lebih besar dari nilai signifikansi yaitu 0,05 (5\%) maka H0 diterima dan Ha ditolak, model yang dipakai penelitian ini adalah model random effect. Karena hasil pengujian chow dan pengujian hausman berbeda, selanjutnya harus menguji dengan pengujian yang terakhir yaitu pengujian Langrange multiplier.

Uji Lagrange Multiplier

Tabel 3. Uji Lagrange Multiplier

\begin{tabular}{cccc}
\hline \hline & & & \\
Null (no rand. effect) & Cross-section & Period & Both \\
Alternative & One-sided & One-sided & \\
\hline \hline Breusch-Pagan & 42.66948 & 1.461213 & 44.13069 \\
& $(0.0000)$ & $(0.2267)$ & $(0.0000)$
\end{tabular}

Dari hasil pengujian dengan uji Lagrange multiplier diatas diperoleh nilai probability pada cross section sebesar 0,0001 dimana nilai tersebut lebih kecil dari nilai signifikansi yaitu 0,05 (5\%) maka H0 ditolak dan Ha diterima model yang dipakai penelitian ini adalah model random effect.

\section{Uji Asumsi Klasik}

1. Uji Normalitas

Gambar 1. Uji Normalitas

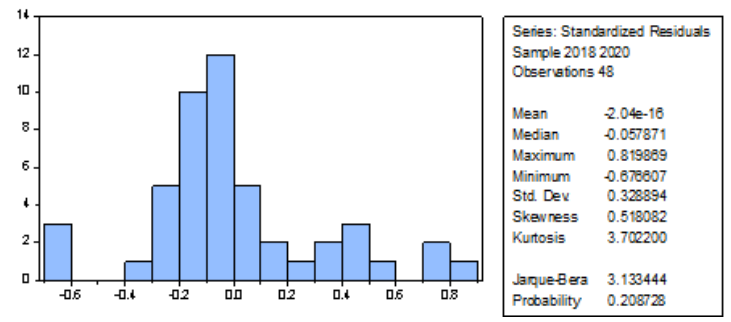

Pada hasil uji normalitas dapat diketahui nilai Jarque-Bera yaitu 3.133444 dengan probability 0.208728 nilainya lebih besar daripada nilai signifikansi $0.05(5 \%)$. artinya data yang dipakai berdistribusi dengan normal.

2. Uji Multikolonieritas

Gambar 2. Uji Multikolonieritas

\begin{tabular}{crrrr} 
& $\mathrm{X} 1$ & $\mathrm{X} 2$ & $\mathrm{X} 3$ & $\mathrm{X} 4$ \\
\hline \hline $\mathrm{X} 1$ & 1.000000 & -0.454971 & -0.368715 & 0.563496 \\
$\mathrm{X} 2$ & -0.454971 & 1.000000 & 0.826918 & 0.101183 \\
X3 & -0.368715 & 0.826918 & 1.000000 & 0.233980 \\
X4 & 0.563496 & 0.101183 & 0.233980 & 1.000000
\end{tabular}

Data diolah oleh peneliti menggunakan eviews 10, 2021

Pada hasil uji multikolinearitas nilai koefisien korelasi antar variabel independen dalam 
| Siti Fatimah, et al.

penelitian ini kurang dari 0.90, diperoleh kesimpulan tidak terjadi gejala multikolinearitas pada variable yang diteliti.

3. Uji Heteroskedastisitas

Gambar 3. Uji Heteroskedastisitas

\begin{tabular}{crrrr}
\hline \hline Variable & Coefficient & Std. Error & t-Statistic & Prob. \\
\hline \hline C & 5.664842 & 5.044689 & 1.122932 & 0.2710 \\
X1 & 0.050813 & 0.092185 & 0.551209 & 0.5859 \\
X2 & 2.891684 & 1.654530 & 1.747737 & 0.0915 \\
X3 & -0.234688 & 0.306516 & -0.765662 & 0.4503 \\
X4 & -0.307076 & 0.279444 & -1.098881 & 0.2812 \\
\hline \hline
\end{tabular}

Berdasarkan hasil uji Heterokedastisitas di atas, nilai Prob variabel struktur modal sebesar 0.2710, variabel ROA sebesar 0.5859, nilai Prob variabel ROE sebesar 0.0915, dan nilai Prob variabel ukuran perusahaan sebesar 0.4503. Dari semua nilai Prob dari masing-masing variabel lebih besar dari 0,05 . Artinya, penelitian ini tidak terdapat masalah heterokedastisitas.

4. Uji Autokorelasi

Tabel 4. Uji Autokorelasi

\begin{tabular}{|c|c|}
\hline Durbin Watson Stat. & 1.578611 \\
\hline $\mathrm{dL}$ & 1.1769 \\
\hline $\mathrm{dU}$ & 1.17323 \\
\hline $4-\mathrm{dL}$ & 2.8231 \\
\hline $4-\mathrm{dU}$ & 2.2677 \\
\hline
\end{tabular}

Berdasarkan tabel output di atas, diketahui nilai dw sebesar 1.578611. Hal ini menunjukkan bahwa tidak terdapat autokorelasi baik autokorelasi positif maupun autokorelasi negatif dalam model.

Berdasarkan uji asumsi klasik di atas, diketahui bahwa semua pengujian data tidak ditemukan adanya pelanggaran asumsi klasik yang mencangkup uji normalitas, uji multikolonierias, uji heteroskedastisitas, dan uji autokorelasi, sehingga data dapat dianalisis menggunakan analisis regresi data panel.

Uji Model Regresi Data Panel

Tabel 5. Uji Model Regresi Data Panel

\begin{tabular}{|c|c|c|c|c|}
\hline Variable & Coefficient & Std. Error & t-Statistic & Prob. \\
\hline $\mathrm{C}$ & 0.521306 & 1.325247 & 0.393365 & 0.6960 \\
\hline $\mathrm{X} 1$ & -0.015002 & 0.053695 & -0.279394 & 0.7813 \\
\hline $\mathrm{X} 2$ & 3.521673 & 1.338539 & 2.630984 & 0.0118 \\
\hline $\mathrm{X} 3$ & -0.567027 & 0.189496 & -2.992296 & 0.0046 \\
\hline \multirow[t]{3}{*}{$\mathrm{X} 4$} & 0.032024 & 0.075830 & 0.422311 & 0.6749 \\
\hline & \multirow{2}{*}{\multicolumn{2}{|c|}{ Effects Specification }} & & \\
\hline & & & S.D. & Rho \\
\hline Cross-section random & & & 0.325946 & 0.7641 \\
\hline Idiosyncratic random & & & 0.181111 & 0.2359 \\
\hline
\end{tabular}

Weighted Statistics

\begin{tabular}{llll}
\hline R-squared & 0.214695 & Mean dependent var & 0.368473
\end{tabular}


Adjusted R-squared

S.E. of regression

F-statistic

Prob(F-statistic)
0.141643

0.177952

2.938945

0.031099
S.D. dependent var

Sum squared resid

Durbin-Watson stat
0.192074

1.361670

1.578611

Dari hasil , maka dperoleh regresi data panel

$\mathrm{Y}=0.521306-0.015002+3.521673-0.567027+0.032024$

Berdasarkan model persamaan regresi diatas, maka

1. Nilai koefisien konstanta sebesar 0.521306. artinya jika yang berarti jika seluruh nilai variabel independen yaitu variable X1 (struktur modal), X2 (Return On Asset), X3 (Return On Equity), dan X4 (ukuran perusahaan). Maka besarnya Y (nilai perusahaan) adalah 0.0521306

2. Nilai koefisien regresi variable struktur modal adalah - 0.015002 hal ini menunjukkan bahwa variable tersebut memiliki pengaruh negatif terhadap variable nilai perusahaan. Artinya jika struktur modal meningkat sebesar satu satuan maka nilai perusahaan akan menurun sebesar 0.015002 dengan anggapan variabel lain nilainya tetap.

3. Nilai koefisien regresi variable return on asset (ROA) adalah 3.521673 hal ini menunjukkan bahwa variable tersebut memiliki pengaruh positif terhadap variable nilai perusahaan. Artinya jika return on asset (ROA) meningkat sebesar satu satuan maka nilai perusahaan akan meningkat sebesar 3.521673 dengan anggapan variabel lain nilainya tetap.

4. Nilai koefisien regresi variable return on equity (ROE) adalah - 0.567027 hal ini menunjukkan bahwa variable tersebut memiliki pengaruh negatif terhadap variable nilai perusahaan. Artinya jika return on equity (ROE) meningkat sebesar satu satuan maka nilai perusahaan akan menurun sebesar 0.567027 dengan anggapan variabel lain nilainya tetap.

5. Nilai koefisien regresi variable ukuran perusahaan adalah 0.032024 hal ini menunjukkan bahwa variable tersebut memiliki pengaruh positif terhadap variable nilai perusahaan. Artinya jika ukuran perusahaan meningkat sebesar satu satuan maka nilai perusahaan akan meningkat sebesar 0.032024 dengan anggapan variabel lain nilainya tetap.

\section{Uji Signifikasi Parsial (Uji T)}

Tabel 6. Uji Signifikasi Parsial (Uji T)

\begin{tabular}{|c|c|c|c|c|}
\hline Variable & Coefficient & Std. Error & t-Statistic & Prob. \\
\hline $\mathrm{C}$ & 0.521306 & 1.325247 & 0.393365 & 0.6960 \\
\hline $\mathrm{X} 1$ & -0.015002 & 0.053695 & -0.279394 & 0.7813 \\
\hline $\mathrm{X} 2$ & 3.521673 & 1.338539 & 2.630984 & 0.0118 \\
\hline $\mathrm{X} 3$ & -0.567027 & 0.189496 & -2.992296 & 0.0046 \\
\hline $\mathrm{X} 4$ & 0.032024 & 0.075830 & 0.422311 & 0.6749 \\
\hline
\end{tabular}

Nilai probability untuk variabel struktur modal sebesar 0.7813 yang berada diatas nilai signifikansi 0.05 menunjukkan bahwa tidak terdapat pengaruh antara struktur modal dengan nilai perusahaan, maka Ho diterima dan Ha ditolak.

Nilai probability untuk variabel Return On Asset (ROA) sebesar 0.0118 yang berada dibawah nilai signifikansi 0.05 menunjukkan bahwa terdapat pengaruh antara Return On Asset (ROA) dengan nilai perusahaan, maka hipotesis 2 diterima.

Koefisien regresi untuk variabel Return On Equity (ROE) sebesar 0.0046. yang berada dibawah nilai signifikansi 0.05 menunjukkan bahwa terdapat pengaruh antara Return On Equity (ROE) dengan nilai perusahaan, maka hipotesis 3 diterima.

Nilai probability untuk variabel ukuran perusahaan sebesar 0.6749 yang berada diatas nilai signifikansi 0.05 menunjukkan bahwa tidak terdapat pengaruh antara struktur modal dengan nilai perusahaan, maka Ho diterima dan Ha ditolak. 
Uji Simultan (Uji F)

Tabel 7. Uji Simultan (Uji F)

\begin{tabular}{|l|r|}
\hline R-squared & 0.214695 \\
\hline Adjusted R-squared & 0.141643 \\
\hline S.E. of regression & 0.177952 \\
\hline F-statistic & 2.938945 \\
\hline Prob(F-statistic) & 0.031099 \\
\hline
\end{tabular}

Berdasarkan hasil uji F diatas, dihasilkan nilai Prob(F-statistic) yaitu 8sebesar 0.031099

lebih kecil dari tingkat signifikansi 0,05. Maka dapat disimpulkan bahwa variable struktur modal, return on asset, return on equity, dan ukuran perusahaan secara simultan berpengaruh terhadap nilai perusahaan.

\section{Uji Koefisien Determinasi (Uji $\mathbf{R}^{2}$ )}

Tabel 8. Uji Koefisien Determinasi (Uji R²)

\begin{tabular}{|l|r|}
\hline R-squared & 0.214695 \\
\hline Adjusted R-squared & 0.141643 \\
\hline S.E. of regression & 0.177952 \\
\hline F-statistic & 2.938945 \\
\hline Prob(F-statistic) & 0.031099 \\
\hline
\end{tabular}

Berdasarkan hasil uji Koefisien Determinasi nilai Adjusted R-squared sebesar 0.141643 atau $14.16 \%$. Hal ini menunjukan bahwa persentase sumbangan variabel independen $(\mathrm{X})$ terhadap variabel dependen (Y) hanya sebesar $14.16 \%$ atau dapat dikatakan bahwa variabel independen yang digunakan dalam penelitian ini hanya mampu menjelaskan $14.16 \%$ terhadap variabel dependennya, sedangkan sisanya sebesar $85.84 \%$ dijelaskan oleh variabel lain diluar variabel yang diteliti.

\section{Kesimpulan}

Berdasarkan hasil penelitian dan pembahasan yang telah diuraikan pada pembahasan sebelumnya maka peneliti mengambil beberapa kesimpulan sebagai berikut :

1. Hasil Uji Simultan dan Determinasi

Hasil Uji F atau uji stimultan menyatakan bahwa besaran Signifikasi yang diperoleh dalam perhitungan sebesar 0.031099 , lebih kecil dari $\alpha=0,05$. Artinya bahwa secara stimultan atau bersama-sama, terdapat pengaruh antara DER, ROA, ROE, dan Size terhadap nilai perusahaan (Tobin's Q) sehingga pengujian ini diterima. Sedangkan pada $R$ Square diperoleh perhitungannya sebesar 0,5725 atau 57,25\%. Artinya, besar pengaruh antara DER, ROA, ROE, dan Size terhadap nilai perusahaan (Tobin's Q) sebesar 0.141643 atau $14.16 \%$., sedangkan $85.84 \%$ dijelaskan oleh variabel lain diluar variabel yang diteliti.

2. Pengaruh tiap variable independen terhadap variable dependen

Dari hasil penelitian ini menunjukkan bahwa struktur modal tidak berpengaruh secara signifikan terhadap nilai perusahaan indeks BUMN20 yang terdaftar di Bursa Efek Indonesia tahu 2018-2020. Hal ini dibuktikan dari hasil uji t variable struktur modal dimana koefisien regresi untuk variabel struktur modal sebesar 0.7813 dengan tingkat signifikan diatas sebesar 0.05 yang menunjukkan bahwa tidak terdapat pengaruh signifikan antara struktur modal dengan nilai perusahaan, Hal ini menunjukkan bahwa struktur modal yang dimiliki oleh perusahaan indeks BUMN20 terdaftar di Bursa Efek Indonesia masih belum optimal untuk meningkatkan harga saham dan memaksimalkan nilai perusahaan. Hasil penelitian ini sesuai dengan penelitian yang dilakukan oleh Monica Yuliani dan Jonnardi (2021) dan Mispiyati (2020)

Dari hasil penelitian ini menunjukkan bahwa Return On Asset (ROA) berpengaruh positif secara signifikan terhadap nilai perusahaan indeks BUMN20 yang terdaftar di Bursa Efek Indonesia tahu 2018-2020. Hal ini dibuktikan dari hasil uji t variable Return On Asset (ROA) dimana koefisien regresi untuk variabel Return On Asset (ROA) adalah 0.0118 yang berada dibawah nilai signifikansi 0.05 . ini menunjukkan bahwa terdapat pengaruh positif signifikan antara Return On Asset (ROA) dengan nilai perusahaan, 
Hasil penelitian ini sejalan dengan penelitian Tunggu Piyama (2021). monica \& junardi (2021) Semakin tinggi profitabilitas maka, nilai perusahaan juga semakin baik. Hal tersebut dapat dijelaskan bahwa tingginya profitabilitas dapat menunjukkan prospek perusahaan yang baik kepada para investor karena para investor akan tertarik pada perusahaan yang memiliki profitabilitas yang baik, sehingga berpengaruh terhadap peningkatan permintaan saham (Chasanah, dan Adhi, 2017). Banyaknya permintaan investor akan saham perusahaan memicu kenaikan pada harga saham perusahaan tersebut. Tinggi rendahnya harga saham yang terbentuk mempengaruhi nilai dari perusahaan (Sari dan Priyadi, 2016).

Hal ini menunjukkan bahwa profitabilitas tinggi dinilai sebagai sinyal positif bagi para investor yang berharap dengan meningkatnya laba bersih perusahaan, manajemen perusahaan akan meningkatkan dividen yang dibagikan kepada para pemegang saham (investor). Profitabilitas perusahaan yang tinggi akan meningkatkan nilai perusahaan karena dari perpektif investor, perusahaan yang mampu menghasilkan profitabilitas yang tinggi artinya perusahaan tersebut mampu mengelola modal yang dimiliki perusahaan.

Pengaruh Profitabilitas Melalui Return On Equity (ROE) Terhadap Nilai Perusahaan

Dari hasil penelitian ini menunjukkan bahwa Return On Equity (ROE) berpengaruh negatif secara signifikan terhadap nilai perusahaan indeks BUMN20 yang terdaftar di Bursa Efek Indonesia tahu 2018-2020. Hal ini dibuktikan dari hasil uji t variable Return On Equity (ROE) dimana koefisien regresi untuk variabel Return On Equity (ROE) adalah 0.0046 yang berada dibawah nilai signifikansi 0.05 dan nilai koefisien negatif sebesar -0.567027. ini menunjukkan bahwa terdapat pengaruh negatif signifikan antara Return On Equity (ROE) dengan nilai perusahaan,.

Dalam penelitian ini berlawanan dengan teori karena profitabilitas yang diproksikan dengan return on equity berpengaruh negatif. Hal ini menggambarkan bahwa semakin tinggi ROE yang dihasilkan maka akan menurunkan nilai perusahaan. Begitu juga sebaliknya semakin rendah ROE maka akan semakin tinggi nilai perusahaan. Berpengaruh negatif mengindikasikan bahwa ROE dipandang investor sebagai suatu keadaan perusahaan yang tidak menentu untuk BUMN di Indonesia periode 2018 - 2020 untuk masing-masing jenis usaha.

Dari hasil penelitian ini menunjukkan bahwa ukuran perusahaan tidak berpengaruh secara signifikan terhadap nilai perusahaan indeks BUMN20 yang terdaftar di Bursa Efek Indonesia tahu 2018-2020. Hal ini dibuktikan dari hasil uji t variable struktur modal dimana koefisien regresi untuk variabel struktur modal sebesar 0.6749 dengan tingkat signifikan diatas sebesar 0.05 yang menunjukkan bahwa tidak terdapat pengaruh signifikanantara struktur modal dengan nilai perusahaan,

\section{Acknowledge}

Puji syukur penulis panjatkan kehadirat Allah SWT karena berkat rahmat dan karunia-Nya penulis dapat menyelesaikan penelitian ini walaupun masih jauhu dari kata sempurna. Dalam pelaksanaan penelitian ini penulis mengucapkan terimakasih sebesar-besarnya kepada orangtua, keluarga, pihak-pihak Universitas Islam Bandung, dosen pembimbing, serta teman-teman yang telah memberikan dukungan dan motivasi kepada peneliti.

Peneliti menyadari bahwa penulisan karya ilmiah ini masih banyak sekali kekurangannya. Namun peneliti selalu berupaya untuk mencapai yang terbaik untuk penelitian ini. Akhir kata semoga penelitian ini bermanfaat bagi banyak orang.

\section{Daftar Pustaka}

[1] Brigham, A. F., \& Houston, J. F. (2011). Dasar-dasar Manajemen Keuangan Edisi 10. Jakarta: Salemba Empat.

[2] BEI. (2021). Laporan Keuangan dan Tahunan. Retrieved from IDX: https://www.idx.co.id/perusahaan-tercatat/laporan-keuangan-dan-tahunan/

[3] Hamidy, R.R., Wiksuana, I.G.B., Gede, L., Artini, S., 2015. Dengan Profitabilitas Sebagai Variabel Intervening Pada Perusahaan Properti Dan Real Estate Di Bursa Efek Indonesia. EJurnal Ekon. dan Bisnis Univ. Udayana 4, 665-682.

[4] https://www.edelman.com/trust/2018-trust-barometer 
[5] https://www.cnbcindonesia.com/market/20180517115937-17-15316/ada-tiga-indeks-barudi-bei-untuk-apa

[6] Mispiyanti. (2020). Pengaruh Struktur Modal, Capital Expenditure, Profitabilitas Dan Kebijakan Dividen Terhadap Nilai Perusahaan Pada Perusahaan BUMN Indonesia. Jurnal Akuntansi dan Pajak, , ISSN 1412-629X 1 E-ISSN 2579-3055, 133-144.

[7] Monica Yuliani, d. J. (April, 2021). Pengaruh Struktur ModaL, Profitabilitas, Likuiditas, dan Ukuran Perusahaan Terhadap Nilai Perusahaan. Jurnal Multiparadigma Akuntansi, Volume III No. 2, 739-747.

[8] Sundana, I. M. (2015). Manajemen Keuangan Perusahaan Teori dan Praktik Edisi 2. Jakarta: Erlangga

[9] Tunggul Priyatama, E. P. (2021). Pengaruh Struktur Modal, Profitabilitas, Likuiditas, dan Ukuran Perusahaan. Jurnal Ilmiah Ekonomi dan Bisnis, 12(1), Mei 2021, 100-106, 100 - 106.

[10] Wiagustini, Ni Luh Putu. (2010). Manajemen Keuangan. Udayana University Press. Denpasar.

[11] Yadnya, N. L. (2017). Pengaruh Struktur Modal, Profitabilitas, dan Ukuran Perusahaan Terhadap Nilai Perusahaan Pada Perusahaan Food and Baverage di BEI. E-Jurnal Manajemen Unud, Vol. 6, No. 12, 6383-6409 